\title{
Constellating Technology: Heidegger's Die Gefahr/The Danger
}

Babette Babich

Fordham University, babich@fordham.edu

Follow this and additional works at: https://fordham.bepress.com/phil_research

Part of the Continental Philosophy Commons, Other Philosophy Commons, Philosophy of Science Commons, and the Photography Commons

\section{Recommended Citation}

Babich, Babette, "Constellating Technology: Heidegger's Die Gefahr/The Danger" (2014). Research Resources. 36. https://fordham.bepress.com/phil_research/36

This Article is brought to you for free and open access by the Hermeneutic and Phenomenological Philosophies of Science at DigitalResearch@Fordham. It has been accepted for inclusion in Research Resources by an authorized administrator of DigitalResearch@Fordham.

For more information, please contact considine@fordham.edu. 


\title{
Constellating Technology: Heidegger's Die Gefahr/The Danger
}

\author{
Babette Babich
}

\begin{abstract}
Heidegger's question concerning technology was originally posed in lectures to the Club of Bremen. This essay considers the totalizing role of technology in Heidegger's day and our own, including a discussion of radio and calling for a greater integration of Heidegger's thinking and critical theory. Today's media context and the increasing ecological pressures of our time may provide a way to think, once again, the related notions of event [Ereignis] and ownedness [Eigentlichkeit].
\end{abstract}

\section{Constellating Technology}

»Die Konstellation des Seyns spreche uns an.«

— Heidegger, Die Kehre

On December 1, 1949, Heidegger addressed the Club of Bremen under the title: Insight Into That Which Is, featuring four sub-lectures, each one lengthy enough to count as a lecture in its own right. ${ }^{1} \mathrm{~A}$ few months later, Heidegger reprised the colloquium in Baden-Baden on two successive days on the 25th and 26th of March, 1950. A popular account of the Baden-Baden lectures in Der Spiegel invokes Heidegger's influence on Sartre and the French Existentialist movement, ${ }^{2}$ but reflects that if it is the image of the philosopher in his Black Forest cabin that "makes

\footnotetext{
${ }^{1}$ Martin Heidegger (1994). Cf. Heidegger (2012) and see for translations of "The Question Concerning Technology" and "The Turn" as well as the additional essays, "The Age of World Picture" and "Science and Reflection," Heidegger (1977b).

2 "Heidegger. Rückfall ins Gestell,” Der Spiegel, 14: April 6, 1950.

B. Babich $(\square)$

Department of Philosophy, Fordham University, 113 West 60th Street, New York, NY 10023, USA

e-mail: babich@fordham.edu
} 
headlines," ${ }^{3}$ the most newsworthy event would be the two day lecture series: described as an "absolute exception," and emphasizing that Heidegger was technically still banned from teaching. There is an obvious dispute about the dates of the official ban ${ }^{4}$ yet what is not disputable is that Heidegger would not resume university teaching at Freiburg until $1951 .^{5}$ What is also not in dispute is that under the Nazis, Heidegger was deemed insufficiently important ("scientifically" or as a scholar) and he was relieved from service in university and re-assigned to service in the Volksturm following the heavy bombing attack on Freiburg.

Towards the end of the war itself Heidegger managed to get permission to relocate his papers to Messkirch and he also offered a conflict-laden reading of Hölderlin in a lecture held in a castle above Beuron to which he and other university faculty retreated, speaking there not on needfulness [Die Not] or desperate times [dürftiger Zeit] but (and much rather), Die Armut, poverty. ${ }^{6}$ Still or in any case, the Spiegel's assertion of an 'absolute exception' seems less than accurate for two days of lectures reprising the one day Bremen lectures held three months earlier. ${ }^{7}$ Indeed Heidegger tells us that he would repeat the Bremen lectures on other occasions, the most well-known of which being a presentation of these lectures in Munich at the Bavarian Academy of Fine Arts in Munich, on June 6, 1950, where he presented the first, second, and last lecture of the series of four lectures presented in Bremen and repeated in Baden-Baden.

The first lecture was titled Das Ding [The Thing], the second Das Ge-Stell—which may be variously translated, most popularly, as "The Enframing" or, more recently, as "The Positionality" or even, with a Brooklyn (and I hope suitably gangster accent) "The Set-Up,"- the third, Die Gefahr [The Danger], and the fourth, Die Kehre [The Turn]. Five years later, in 1954, Heidegger featured the central themes from these lectures in his Vorträge und Aufsätze, published in 1954, in which Die Frage nach der Technik, "The Question Concerning Technology," has pride of place as the first chapter, followed by "Science and Reflection" and so on. ${ }^{8}$ Indeed, had Heidegger scholarship been differently, hermeneutically minded, rather as Joe Kockelmans has been able to

\footnotetext{
${ }^{3}$ Ibid.

${ }^{4}$ The suspension of Heidegger's right to teach was imposed 1945-1949 but Heidegger would not resume teaching until 1951, as Heidegger's own comment on Richardson's "Appendix" to his Heidegger: Through Phenomenology to Thought indicates, Richardson (1993), 678-679. The recommendation of a period of 5 years appears in Jaspers' Gutachten but as Günter Figal has noted, among others like Rüdiger Safranski, the prohibition was indeed lifted as of 1949, although Heidegger would not officially "resume teaching until after assuming emeritus status in 1951." In: Figal (2006), 38. See for an overview of relevant primary sources, Martin (1989).

${ }^{5}$ There is some ambiguity as to what might be meant by a Berufsverbot or Lehrverbot and the Spiegel article suggests that this refers to university as well as general or public lectures, such that Heidegger's commemorative lecture Wozu Dichter?, presented in 1946 in honor of Rilke would/ should also be counted as ,lecturing.'

${ }^{6}$ Heidegger's June 27, 1945 Beuron lecture "Die Armut," is apotheosized by Lacoue-Labarthe in his introduction to Heidegger (2004).

${ }^{7}$ Here too, if we are counting the ways Heidegger might be considered as 'teaching,' one may also count a radio broadcast in 1951. Heidegger (1951); courtesy of Klett-Cotta und WDR.

${ }^{8}$ See Heidegger's (1978 [1954]a, b).
} 
read Heidegger, along with a few others like Ted Kisiel, like Hans Seigfried and Patrick Heelan, all of whom read and foregrounded Heidegger's thinking in the mid1960 s through to the early 1980 s on the topic of technology and modern science, Heidegger's collection of his Lectures and Essays (as yet untranslated as such) might well have set the tone for the post-war Heidegger reception.

But as it happens the history of the reception of a thinker's ideas is often the history of the reception of the translation of those ideas. Thus Ralph Manheim's translation of Heidegger's Introduction to Metaphysics, first translated in 1959 and thus in advance of Macquarrie and Robinson's translation of Being and Time in 1962 along with the 1971 translations of the studies of poetry, language, and above all the essay on the origin of the work of art, would entail for Anglophone readers that Heidegger's reflections on science and technology were relegated to second tier in Heidegger scholarship. ${ }^{9}$ Yet things are not all that different in France, though one may note Dominique Janicaud as exception and Rainer Bast, Ewald Richter, and Carl-Friedrich Gethman in Germany. ${ }^{10}$

Today, in English language studies we may have the preconditions for a change in English language Heidegger scholarship with Andrew Mitchell's new translation of the Bremen and Freiburg lectures. ${ }^{11}$ But the comparison of French and German studies tells us that we should expect to take some time to add the question of Heidegger and science to the issue of technology, a compound concern that and along with his thinking on art Heidegger always saw in terms of what I am here seeking to articulate as a constellation.

It was this same constellation that was in view for Kockelmans himself who, along with the already mentioned Hans Seigfried and Patrick Heelan, authored important early studies of Heidegger and the sciences. ${ }^{12}$ Kockelmans also went on, together with Ted Kisiel, to dedicate an important collection to framing this thought constellation within continental philosophy of science, with the alas relatively utterly unreceived but indispensable collection, Phenomenology and the Natural Sciences, ${ }^{13}$ together with Kockelmans' own single authored Heidegger and Science, ${ }^{14}$ which Kockelmans was able to explore as a central theme of his own

\footnotetext{
${ }^{9}$ Cf. Heidegger $(1959,1962)$ as well as Heidegger (1971).

${ }^{10}$ See, in particular, Janicaud (1985), as well as (patently: in addition to others, both earlier and since): Bast (1986), Richter (1992) and see too Gethman's (1991) as well as Seigfried's (1991), respectively.

${ }^{11}$ Heidegger, Bremen and Freiburg Lectures, as cited above.

${ }^{12}$ Instructively, the American tendency to fail to mention German and French scholarship on the topic of Heidegger's philosophy of science and above all to exclude mention of work done by Kockelmans or Heelan, see for a recent instance, Heelan (2012) or Richardson as well as Seigfried in favor of voices supposed to be received (at the time the names mentioned in passing were Hesse, Lakatos, and Feyerabend, although the article's actual citations were limited to Kuhn) characterizes Jack Caputo's essay (1986). To be sure, Heidegger's philosophy of science cannot be discussed apart from Heidegger's engagement with Husserl and Kant and above all perhaps with Nietzsche. See for this context, Babich (2010a).

${ }^{13}$ Kockelmans and Kisiel (1970).

${ }^{14}$ Kockelmans (1985a).
} 
research while also publishing in the same year a wide ranging study in Nijhoff's influential Phaenomenologica series on Heidegger on Art and Art Works. ${ }^{15}$

The story of continental philosophy of science and Heidegger is a complicated one, not able to be related here but at the same time unable to be dispensed with as it very directly affects the reception of Heidegger in philosophy of science in particular but also in philosophy in general. ${ }^{16}$ Thus the fortunes of continental philosophy as such and in contest with analytic philosophy and the overarching ressentiment of things French and especially in the post-war years of things German make a difference as well. In addition, analytic philosophy (as I argue elsewhere $)^{17}$ has tended to be especially suspicious of Heidegger's focus on questioning or critique. To this it should also be acknowledged that critique per se had been associated ever since Immanuel Kant himself with the encroaching danger of nihilism, thus Heidegger's 1939 lecture courses on Nietzsche's epistemology (entitled "The Will to Power as Knowledge") and 1940 course on "Nihilism" hardly helped matters in this regard..$^{18}$ But as with many things, there is much more than a single influence or factor. ${ }^{19}$ That these factors continue to interweave and play in current understanding is also something I hope to foreground in what follows.

The Bremen lectures for their own part draw on formulations unpublished (the Beiträge) as well as published as we recall Heidegger's 1946 "Letter on Humanism,"20 a letter composed in reply to the Jean Beaufret's question to him in the wake of the devastation of World War II, prompted in part in response to Jean-Paul Sartre's Paris lecture in the same post-war year: Existentialism is a Humanism. ${ }^{21}$

\footnotetext{
${ }^{15}$ Kockelmans (1985b).

${ }^{16}$ See, again, in general, Babich, "Towards a Critical Philosophy of Science" and with specific reference to Heidegger, see Babich (2012, 159-192 and 2013b). In addition to Trish Glazebrook's introductory overview: "Why Read Heidegger on Science?" in: Glazebrook, ed., Heidegger on Science, 13-26, see too in the same collection Richter, "Heidegger's Theses Concerning the Question of the Foundations of the Sciences" (67-90) as well as important contributions by Heelan, "Carnap and Heidegger: Parting Ways in the Philosophy of Science" (113-130) as well as Ute Guzzoni "Gelassenheit: Beyond Technoscientific Thinking" (193-204) and Kiesel's "A Supratheoretical PreScientific Hermenutics of Scientific Discovery" (239-260).

On Heidegger and the disciplinary profession of philosophy as such, especially but not only in Anglophone culture, see Babich (2003), 63-103.

${ }^{17} \mathrm{See}$, for one example, a recent interview, Babich (2011), 37-71.

${ }^{18}$ See for these courses: Heidegger (1991).

${ }^{19}$ Kleinberg's (2005) is, I think, a useful addition here, especially in the postwar context, but see too for the pre-war context the now-standard reference on Heidegger-Carnap, Friedman (2000)—cf. Heelan's essay "Carnap and Heidegger" cited above-enhanced in depth by Gordon's (2012).

${ }^{20}$ Heidegger (1954). Additional elements, were we tracing the history of the lectures themselves can also be found in Heidegger, Beiträge zur Philosophie and so on. Heidegger's (1977c) and the same translation is also included in the English edition of Heidegger's Wegmarken by MacNeill (1998).

${ }^{21}$ Jean-Paul Sartre $(1946,2007)$.
} 
The Thing (the first of the lectures later reprised in Munich), is also included in Vorträge und Aufsätze, together with Heidegger's prefatory "Hinweis" or contextualizing reference to the 'shrinking' of time and space through the same wellknown technological means that continue to shrink distances to this day. And as already noted, eight years later, a little contribution based on the Bavarian lectures also appears as the first in the Neske series Opuscula aus wissenschaft und dichtung, entitled Die Technik und die Kehre and duly citing the context of the original lectures. ${ }^{22}$

As a consequence, by 1962 all but one of the original four lectures had been published, in one variant or reprise or another. My theme here focusses on that otherwise unpublished essay, "The Danger," Die Gefahr, although and of course parts of the text are assimilated into The Question Concerning Technology. As this point of assimilation also makes clear, a discussion cannot but include reference to all four, especially Das Ge-Stell.

The thoughts Heidegger gathers together in these lectures, given as we are told, and let it be noted again, over the course of a single day, and hence in a single breath (the German celebrates just this capacity, doubtless due to the length of their sentences: der lange Atem being a term of approbation), go back to the Beiträge, Heidegger's supposed second major work, but a work scholars now largely disregard (after the initial flurry of interest). ${ }^{23}$ These days and already for some time we have tended to focus on what we take to be the early Heidegger-roughly the preBeing and Time Heidegger, this being the bailiwick of either the very pious, literally so, Heideggerians, or else those who follow and trace the origins of Heidegger's original thinking in the spirit of Ted Kisiel's genealogical, phenomeno-philological brand of Heidegger-hermeneutics. Then there is the later Heidegger, corresponding largely to the Heidegger discussed here, but many people, especially in literature departments also take this to be the Heidegger of Poetry Language Thought and On the Way to Language, and so on all the way to Time and Being and the Discourse on Thinking as well as the later seminars.

And yet the division into early Heidegger and late Heidegger, corresponding to Heidegger I and Heidegger II, is problematic. Heidegger himself politely points this out by foregrounding entanglement, rather in the guise of his Being and Time discussion of future temporalization (out of the past) in his "Letter to Father Richardson," telling us (not really very helpfully) that

only by way of what [Heidegger] I has thought does one gain access to what is to-be-thought by [Heidegger] II. But the thought of [Heidegger] I becomes possible only if it is contained in [Heidegger] II. ${ }^{24}$

\footnotetext{
${ }^{22}$ Heidegger (1962).

${ }^{23}$ Heidegger's originally unpublished Beiträge: vom Ereignis was published in his collected works in advance of the schedule Heidegger had envisaged. It is also available in English in different editions, under two species of translation.
}

${ }^{24}$ Heidegger (2003), 8. 
To take up Heidegger's third lecture, Die Gefahr, it will be necessary to refer to the lecture just preceding it on the technological frame or setup, Das Ge-Stell. Here, I'd like to speak of the language thematic of both lectures (Ge-fahr, Ge-Stell) in a way that is not made easier by the limitation of addressing the question in English, as I am inevitably doing and just to the extent that the English translations cannot but efface the prefixes in either case. The patent point is that these two words, as different as they are, share the same prefix Ge- and that this is relevant as a word form and substantively. Although it is not often done, it's important to take note of this because Heidegger's mode of thinking through what he calls his Insight Into That Which Is tacks a path through related notions (i.e., that which is). In this respect he includes as the core of his lectures, two themes formed with a prefix, the "Ge-," a prefix, as we will all remember from Heidegger's The Question Concerning Technology, that he considers so very important that he talks about it there just as he does in Das Ge-Stell, focusing on the painfully ungainly Ge-Stell, taking it apart, literally by hyphenation and at what can appear to be surprising length. This gives (or should give) a translator pause and William Lovitt, to his credit, thought about the challenge it presented in his translation of The Question Concerning Technology $y^{25}$ and Andrew Mitchell, who has just published his translation of the original four lectures with Indiana Press also gives his reasons for his rendering (though some may have wished for more detail than the few lines he offers). ${ }^{26}$

The rendering of Gestell/Ge-Stell as "framework"/"positionality" may be due to little more than the politics of re-translations, for and after all, a translator has to change enough in order to justify the effort, and it can seem that where Lovitt has "enframing," Mitchell simply inserts, it can appear to have been a kind of cut and paste, "positionality." Thus Mitchell's translation, which is a fluid one, has a dangerous side of its own as it tends to favor a one-to-one style of translation of the sort that today's Cambridge University Press translations have made into a kind of analytic gold or plastic standard, perhaps this begins with the Fichte and Hegel translations, but it is also (with some considerable and disastrous consequences) in evidence in the Cambridge Nietzsche editions. According to this standardizing standard, one finds an equivalent and settles for it, and to this extent the glossary in the Mitchell translation is more literal than say the listing to be found in Macquarrie and Robinson, for example. ${ }^{27}$

Gestell, a kind of physical array or constellation, means framework or structural outline or scaffold. The word is significant because Gestellung also means muster, and one can be ordered to such a mustering, commandeered or called up to service. As is familiar to those of us who know his concern with the fortunes of technology, traditional and modern, what Heidegger wishes to do here, after he has set up his initial tracing reflections on modern technology per se, is to tease out the

\footnotetext{
${ }^{25}$ In addition to his note on the transforms affected by such prefixes in his introduction (p. xx), see William Lovitt's footnote 17 in his translation of "The Question Concerning Technology," in: Heidegger (1977a), 3-35, here p. 19. Cf. note 14, p. 13, as well as notes pp. 15-16, pp. 16-17.

${ }^{26}$ Andrew Mitchell (2012), xi.

${ }^{27}$ Mitchell, "English German Glossary," in: Heidegger, Bremen and Freiburg Lectures, 173-198.
} 
determining or destining set up that is part and parcel of modern technology as this intricately ordered and dependent set up is opposed to the cognate fitted-togetherness but individually separable configuring of old-fashioned equipmentality, as such. Tools qua tools have always involved referentiality. This is what Heidegger calls Bewandtnis and it is the subject of his memorable analysis of handiness-handhabbarkeit-in Heidegger's in Being and Time discussion of Zuhandenheit (BT 98/69), namely readiness-to-hand and in turn and presuming such a readiness in its modality as "unreadiness-to-hand," the revelation of "being-just-present-at handand-no-more" (BT 103/73) as these fit together precisely in such a work context. Using a hammer for a given project, whether it involves the kind of complexity that would have engaged Heidegger's own father as a cooper or joiner (these are related carpenterly professions, but the unions to this day keep them well distinct), or just hanging a picture on the wall, one is referred to a nail or, if this is a metal-free project, think of a trip to IKEA or more romantically, think of Eric Sloane's America where nails were expensive and using wood's properties part of Yankee or New England ingenuity (read thrift or cheapness), with the hammer will go the pegs or cleats. $^{28}$ The difference however is that the same claw hammer that nails nails, removes nails (note that this does not apply to German hammers, they do not come with a claw as one is meant to remove one's nail with the proper tool) and the same hammer, German or Sears Craftsman style can be used to break through a wall if one wishes to remodel a kitchen or for other purposes of the sort and in my classes on Heidegger's Question Concerning Technology, I sometimes like to imagine circus acts, cirque du soleil meets gas station mechanic, juggling with three and then four hammers and so on-these have to be claw hammers for the sake of showmanship and counterpoise. Modern technology quite specifically does not work like that. If you misplace the charger for a new cellphone, you will find that using one of the chargers in your collected array of chargers from cellphones gone by will be an exercise in futility. Connectivity is the point. Modern technology, Heidegger argues, goes beyond the traditional in-order-to of particular kinds of equipmentalities, the kind of practical ordering or for-the-sake-of-which that Aristotle lists for us with reference to the bridler's art in the very first section of the Nichomachean Ethics. In Being and Time, Heidegger refers to the aforementioned workshop array of tools but he also lists the items on his own desk as tools of a kind: paper, desk blotter, fountain pen, ink and so on. So today we might add to all those desk items, a computer, printer, internet connection, surely all this is the same-just update. Heidegger thinks not and his four Bremen lectures, "Insight Into That Which Is," try to explore what is different in modern technology and that is to say to raise the question regarding technology as a question, just as we might remember that he has been at pains to point out just how hard it is to ask after anything at all beginning with Being and Time, section two of which unpacks what it means to question.

Thus and just to offer a contrasting illustration of the romantic sort that we can use to document modern progress, Heidegger used a handsaw of the kind that requires two workers to cut wood for use as fuel in the cabin his wife had arranged

\footnotetext{
${ }^{28}$ See for example, Sloane's (2004 [1965]).
} 


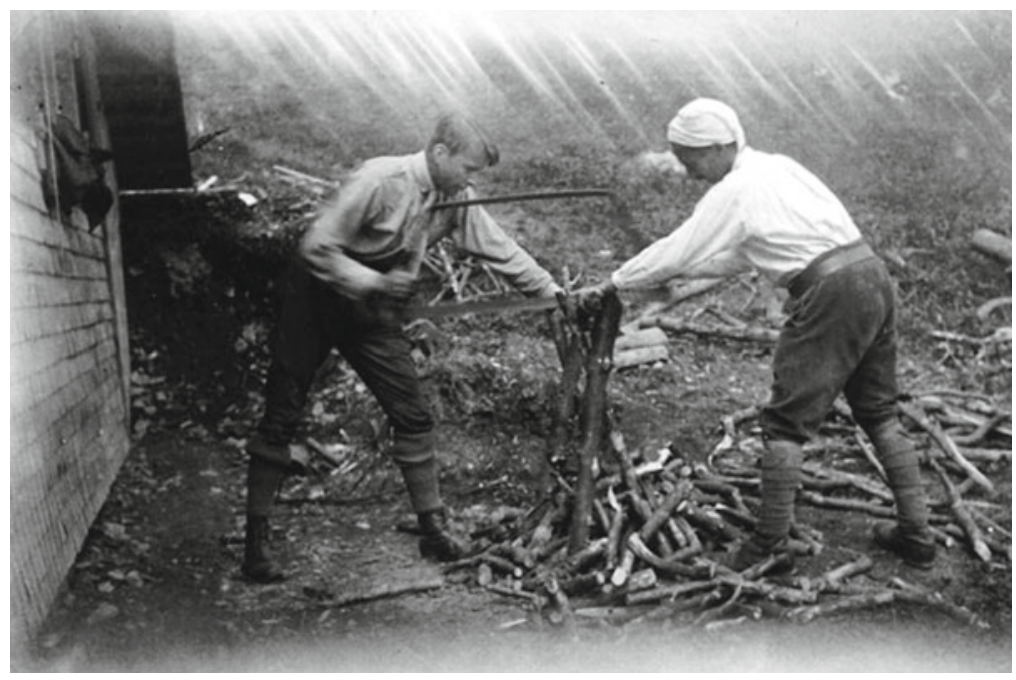

Fig. 1 Hans-Georg Gadamer and Martin Heidegger, Todtnauberg, 1923. Bildagentur dpa

to have built for him in 1922 and for which wood-cutting task he required the efforts of one of his students, my own teacher Hans-Georg Gadamer.

Heidegger later sent a picture commemorating this moment to Gadamer as a gift on his 75th birthday in 1975 and Gadamer thus includes it, with Heidegger's note, in his Philosophische Lehrjahre. ${ }^{29}$ The picture dates from 1923, that is: preBeing and Time, which would thus make this image, for those who like these terms, a picture of Heidegger I (Fig. 1).

Let me note just because it matters in the current context that pants of the kind worn by both Heidegger and Gadamer in this picture did not in fact testify to some kind of back-to-the-land fascist movement but were standard for the time and there are photos of my own father, who was born in New York City in 1935, wearing short pants (i.e., not shorts) of a similar fashion, in pre-war NYC, circa 1940 or ' 41. Details like these, ontic as they are, do not deter folk who have assumed that this picture must date from at least a decade later, say circa 1933, or must even be a postwar image, those who might claim that it provides iconic evidence for Heidegger's nostalgia for the past. For my part, I take the irony to be the labor itself as, like Tom Sawyer, Heidegger commandeers Gadamer's assistance to help him cut some wood, ironic because of Gadamer's later recollection that when he first met Heidegger he took him for a manual-laborer - a Hausmeister-in NYC that would be a super.

The thing about a two handed bow saw is that the 'Gestell' involved to support the wood being sawed has as such no particular connection to the saw or the piece of lumber. It is called a saw horse, technically, just as other Gestell types count as clothes horses or racks, umbrella stands and the like, and you can buy these too at

${ }^{29}$ Hans-Georg Gadamer (1995), 33. 
IKEA and a pair of them will help you cut plywood but can also serve to hold a dinner table perfect for a fashionable loft kitchen. The components can be used together or not, they are severable with respect to use but also distance and thus they are more rather than less self-contained. Heidegger was therefore using the support of such frames to position wood to cut with a bowsaw, given Gadamer's help, given his wife's gift to him of a house in the high hills of the black forest (they are not really mountains), rural land that was then, as a lot of land still is, without convenient access to electricity, ${ }^{30}$ for example, although there was, and that would be a sine qua non, water afforded by the famous spring to which Celan would dedicate his poem Arnica, Eyebright, Arnika, Augentrost. ${ }^{31}$

By contrast and this is the point Heidegger seeks to make throughout, modern technology, modern tools, power tools are different and everything turns on power and its dependencies: thus nature in the purview of modern technoscience becomes on Heidegger's analysis something that it never was until modernity: a giant gas station, a source for the development of natural resources, meaning energy, meaning electricity. In the case of a power tool you are tied to that referentiality by the cord, even if you have a cordless drill, because as Hurricane Sandy reminded us in New York City, you really need to charge cordless tools, including laptops and iPads and cellphones. So whether it is an outlet (this becomes a kind of holy grail for students looking to plug in their laptops or travelers looking to do the same), or extension cord, they all point to the need for electricity, and all the stuff you will have to think about if one gets a job at NYU (at NYU pay) and wishes to build a cabin of one's own upstate in New York's Putnam county, say, you'll need water, cable, the works, and all that will be a pre-requisite before you can get to reflect upon Heidegger's observation that a mechanical tool "is nothing that separately presences for itself." 32 In other words, that is to say that even in its components, i.e., qua taken apart, as he also speaks about automobiles broken down for shipment, modern technology requires far more than just completeness unto itself to be able to be set in motion. Thus contrasting the modern technological apparatus with a self-propelled wheel assembly, like the spinning wheel or else like the "bucketwheel in the rice fields of China" as he invokes these still in use in rural china,

\footnotetext{
${ }^{30}$ By the time the cabin was built it likely had electricity. Germany had electric lighting since the 1880s and by 1913 a good many households as well as the university in Freiburg itself used electricity. See for instance, Chickering (2007).

${ }^{31}$ Celan's poem was written after his 1957 visit to Heidegger's hut in the Black Forest and was included in a collection of Celan's poetry entitled Lichtzwang published shortly after the poet's death in 1970. The title of the poem, Todtnauberg, is a metonymic allusion to place and the rest of the poem seems to do the same: Arnika, Augentrost, der/Trunk aus dem Brunnen mit dem/ Sternwurfel drauf,//in der/Hütte,/die in das Buch/—wessen Namen nahms auf/vor dem meinen?_,/ die in dies Buch/geschriebene Zeile von/einer Hoffnung, heute,/auf eines Denkenden/kommendes/ Wort/im Herzen,//Waldwasen, uneingeebnet,/Orchis and Orchis, einzeln,/Krudes, später, im Fahren,/deutlich,/der uns fährt, der Mensch,/der's mit anhört,//die halb-/beschrittenen Knüppel-/ pfade im Hochmoor,//Feuchtes,/viel."Paul Celan (1980), 240-241 and (2000), Vol. 2, 255-256. See for one discussion, Lyon (2006). See too Herman Rapaport's chapter "Forces of Gravity" in his Is There Truth in Art? (1997), 110-143.
}

${ }^{32}$ Heidegger (1994), 34. 
modern technological machinery only "stands" or works as such "when it goes." If the machine is out of order, if requisite parts are missing, it is worse than nothing and now we are back to the sheerly present at hand (or the irremediably present at hand in the case of those old power cords that connect to appliances or tools one no longer has). Here Heidegger is concerned to attend to the ordering of both the machine and the mechanical network into which it is set just in order that it might be a mechanism of this or that kind. Thus as noted, he also gives the example of the automobile, pointing out that the automobile is more than a tool made of separable parts into which it can be broken down and out of which it can be assembled but exemplifies modern technology to the extent that its use, and intriguingly this has been the subject of several politically theoretic studies of technology, requires an entire schema, a constellation or network, all of it sine qua non. This is not merely a matter of fuel and and a network of fuel stations, of building a network of roads for automotive use and redesigning entire downtown urban areas to include parking garages and highways that pass over or pass through a city and so on. Thus Langdon Winner and others talk about the concerted efforts in the early decades of the last century to demolish street cars and established forms or networks of public transport to shift consumers of public transportation, which cost whatever it cost for a ticket, to consumers of private transportation which required a whole lot more in the way of direct and indirect costs. ${ }^{34}$

Private vs. public transportation underlines Heidegger's point. Hitler built the Autobahn and his system of roads (still a fetish factor in Germany-Freie Fahrt für freie Burger, where the emphasis is on free, meaning no speed-limit) was as beneficial for the nation in peacetime as in wartime. Thus Heidegger can remind his Bremen businessmen that unlike the jug that he uses to illustrate the thing in his first lecture, the automobile does not "just" stand there even when it is parked. Instead it is "at the ready," precisely available for use in every potential or possible sense. Hence the automobile, and by extension, the truck for industrial transportation "is able to be challenged forth precisely for a further transport, which itself sets in place the promotion" - and in good, Rotary Club, English we might prefer to say that this potential to be challenged forth drives the wheels- "of commerce" 35

Here Heidegger goes on to clarify the way in which we are today set up, as it were, to be consumers of precisely the technological schema or framework or, to use Jacques Ellul's term for the very same thing, the technological system, because the point concerning technology is that there is no having of it by halves. You cannot opt out, you cannot take it or leave it — the later Heidegger-Heidegger III we could say-suggests in his Discourse on Thinking that we might do a kind of zen thing with technology, a kind of mindfulness he called Gelassenheit, but like zen and like

\footnotetext{
${ }^{33}$ Ibid.

${ }^{34}$ Langdon Winner offers a discussion of this point along with a number of references to classical political studies of the shift from public to private transport on the eastern and western seaboards in Winner (1986).

${ }^{35}$ Heidegger (1994), 35.
} 
mindfulness (Heidegger called this thinking), Gelassenheit turns out to be more elusive or harder than it sounds.

For Heidegger, "the forester who surveys the wood to be felled"- the line here is reproduced in its entirety in "The Question Concerning Technology"- traces and does not trace the path followed by his grandfather just to the extent that the wood he cuts is ordered, set up for and into the lumber industry which is ordered or fit into producing "cellulose stock" for the paper industry which in turn is set up for delivery "to the newspapers and tabloids that impose themselves on the public sphere in ordered to be devoured by it." 36 If the Frankfurt School were not disposed to reject everything Heidegger notes (after all Horkheimer would still have all the priority one might wish) there is a useful critical analysis in the next paragraph, which does not indeed appear to the same extent in the later essay The Question Concerning Technology. Thus Heidegger here touches upon themes echoing those of Horkheimer and Adorno in their own 1944 Dialectic of Enlightenment-elements of which grew out of Adorno's work, begun in 1941 on Lazarsfeld's Princeton radio project ${ }^{37}$ —along with Friedrich Georg Jünger as well as Herbert Marcuse, in addition to Günther Anders (the stepchild of the Frankfurt School) as indeed Rudolf Arnheim, points also approached from a different point of view by Edward Bernays and Vance Packard. ${ }^{38}$

The point is media, and Heidegger goes on to talk about radio and film in order to explain the very way that the human being him- or herself is disposed of, imposed upon, precisely with respect to his or her disposition as such:

Radio and film belong to the standing reserve of this commandeering [of the human being] through which the public sphere [Offentlichkeit] is set up, challenged forth, and thereby installed in the first place. ${ }^{39}$

For Heidegger, this is not merely the work of the "radio broadcast advisory council" but is already at hand in "the standing reserve called the radio, i.e., challenged forth to the ordering of the broadcast industry." 40

My point is to call attention to a remark that Heidegger offers in a phrase uncannily similar to Adorno's physiognomic observation regarding the twirling of the

\footnotetext{
${ }^{36}$ Heidegger (1994), 37.

${ }^{37}$ See Adorno (1945). See for the results of the Princeton Radio Project, Adorno (2006) and see too Thomas Y. Levin's contextual discussion, which to be sure does not connect Adorno with either his contemporary Anders much less, given the same contemporaneity, Heidegger: Thomas Y. Levin with Michael von der Linn (1994), 316-324. See for further discussion and further references Babich (2013a), Chap. 6.

${ }^{38}$ Vance Packard's (1957) is a popularized discussion of the then-well-established effects of Edward Bernays' (1928). Bernays' work is better known under the rubric of Public Opinion Research or Motivation Research, and is of course all about advertising or marketing but which was originally developed (and is still used) for the political purpose of shaping public opinion-as its original name indicates. For a discussion with respect to television, see Günter Anders cited below as well as independently of Anders, the Canadian political theorist, Dallas Walker Smythe (1954), 143-156.

${ }^{39}$ Heidegger (1994), 37.

${ }^{40}$ Ibid.
} 
radio dial but also in a context akin to the "homeworker" analysis that would be offered by Günther Anders in 1956, which piecework manufacturing in turn produces or generates the media consumer qua media consumer, a point to be taken up by the Canadian media-political theorist Dallas Smythe, arguing and in the process explaining why commercial broadcast access is of value to manufacturers, that, in Heidegger's words here

every radio listener who turns its dial is insulated as part of the component character of the parts of the standing reserve, locked in as a piece of the standing reserve, in which he remains confined even if he still thinks he is utterly free to turn the device on and off. ${ }^{41}$

Paralleling his trademark tool example, Heidegger observes that even if one were to turn off the radio, one would remain connected or bound to it. Indeed as I have argued to be typical for Heidegger's style of intensification, he emphasizes the point with an iconically philosophical thought example: were a cosmic miracle suddenly to silence all radio broadcasts, so Heidegger argues, the very same connection would still persist. ${ }^{42}$ On this extreme supposition, even if:

suddenly everywhere on earth in everyplace, radio receivers were to disappear-who could comprehend the cluelessness, the boredom, the emptiness that would at a blow assault the human being and thoroughly unhinge their routine affairs. ${ }^{43}$

This is also, though that is a paper of its own, the reason for Heidegger's extended reflection on what is involved when a particular tract of land is challenged forth to produce coal, which is in turn demanded by the electrical industry which itself deploys a massive set up just to be able to convert coal into steam, into power for industrial and private use. Heidegger uses this example because such industries and their interconnections (especially all the details we tend not to think about) were transparent to him as they were to every German, every Frenchman, etc., etc., after the war. Thus the competing desire to use land for mining (raw materials) clashed with the need to use land for agriculture (foodstuffs), but the technization of both handcrafts, only meant that the one application namely mining or as we call it today: land use development, demanded vastly more land than ever before, and the second application, farming, also took more land in its mechanized variety than had been traditionally needed.

But the economics of competing land applications and how they might be parceled out and to which interest groups concerned Heidegger less than the very complicated array or constellation of modern scientific, technologized industry as such.

\footnotetext{
${ }^{41}$ Ibid. Anders himself offers a sustained discussion of this counter-example in "Die Welt als Phantom und Matrize. Philosophische Betrachtungen über Rundfunk und Fernsehen"in his 1956 book, Anders (1980), 97-214.

${ }^{42}$ Heidegger's thought example has been 'real' (or Baudrillardian 'integratedly real') for some time and as newspaper reports of New York residents reported (and my own students attested) during Hurricane Sandy, when they couldn't charge cell-phones and usual avenues of internet access were down - today that would be the wireless equivalent of what radio was in 1949-there was great anxiety.

${ }^{43}$ Heidegger (1994), 39.
} 
Thus in addition to his coal example, or airplane example (in the original lecture as we have just cited it, he talks about automotive components packed for export as items of so much standing reserve-present at hand we could say —and parking lots and highways, as components of the automotive industry, all very patently ready to hand). Likewise as also noted, Heidegger focusses on forestry, the woodsman today as compared to his forebears and with that he is off with a discussion of forest management practices, which means harvesting, i.e., cutting down the trees for the sake of and exactly as cued to the needs of other industries as we have just detailed these: like the enormous need for paper after the war, be it for planning or for journalism, which industry also catches Heidegger's attention as it is this same industry (this is the point he makes about radio) includes human beings who are themselves parts of this same industry, ordered into it, set up into it, to the extent that both paper journalism and radio are so many culture industries to use the language that Horkheimer and Adorno and Anders also employ to speak of these media enterprises, as such public industries, as Heidegger explains, are used to direct or set up the "public sphere" so that it may be challenged forth and ordered, i.e., so that public or political planning can proceed according to political design. Indeed as Heidegger certainly knew - the political fate of Germany depended upon it - such public sphere planning was quite explicitly at issue. The question at hand was at the time: what kind of government would rebuild the country? What direction would it take? ${ }^{44}$ If it can be argued that in West Germany, excluding socialism would have to be politically overdetermined, Marx himself had offered serious critiques of the kind of advantage capitalism takes in the time of crisis and had already analysed that the only efficiency served was that of profit. Heidegger makes this point in his own lectures, an emphasis repeated in his "Building, Dwelling, Thinking," 45 which was of course all about the urgent misery of the housing crisis, which was also at the time a food crisis and his "Letter on Humanism" culminates with references, among other things, to Marx, as we note by considering his contrast between thinking and doing, contending that "thinking is a deed" and continuing by emphasizing such a deed "also surpasses all praxis." ${ }^{16}$ For Heidegger, however the thought in question, the 'understanding' of the world that Marx had famously attributed to all philosophy heretofore in his Theses on Feuerbach, would not be marked by anything like "the grandeur of its achievements" or indeed efficacy as such "but through the humbleness of its inconsequential accomplishment." ${ }^{\prime 77}$ Here in the Letter on Humanism, and presumably Heidegger would have known exactly what he was saying by writing this, the conclusion points to the same constellation of philosophy as a project of understanding the world or changing it, and Heidegger suggests that theory itself

\footnotetext{
${ }^{44}$ The beautiful German coin, a 50 pfennig piece issued the same year and featuring a young woman planting a small bush, offers an iconic illustration of this very concern.

${ }^{45}$ Cf. Heidegger, "Building, Dwelling, Thinking” in Heidegger (1971), 143-161.

${ }^{46}$ Heidegger (1977c), 274. I note that Heidegger already is in dialogue with communism, and its anticipated threat in his lecture Die Armut.

${ }^{47}$ Ibid.
} 
can use a bit of reflection on itself and what it is capable of: "It is time to break the habit of overestimating philosophy." 48

The problem here is already one I have been framing out: that is the problem of the Ge-Stell as this parallels the frames set up to re-build houses or indeed cathedrals in Freiburg as the cathedral there was damaged during the war ${ }^{49}$-if you visit and climb to the top you can see that the Freiburg residents set a plaque to thank the stones, as it were, for not falling. And to be sure, as those of us who live in the city know all too well, once a scaffolding goes up around a building to repair it or what have you, its durability seems guaranteed. ${ }^{50}$ The scaffolding, the framework, the set up, is not only indispensable but all-pervasive.

Thus when we read the essay Das Ge-stell, the set up or the setting up, you can also say the enframing (I have already noted that my concerns about 'the positionality,' just to the extent that it can sound like a Kama Sutra move or some Deepak Chopra trademarked approach to heated or Bikram yoga), or indeed when we read Die Gefahr, we are confronted with Heidegger's most notorious comments on the technized transforms of industry and its consequences. Heidegger looks at what the mechanization of anything and everything does, and points out that it does not fail to affect us in the most basic way.

Thus Heidegger writes about the requisitioning and planning that characterized a wartime and a postwar Nachkriegszeit Germany, and he would certainly know about both as he himself (qua dispensable) had been set into, conscripted into service at the end of the war. For in wartime everything was placed at the disposal of this kind of ordering and everything came to be regarded, this is the effect of the transformation of this kind of ordering, as so much standing reserve. We even may remember, it's a postmodern meme, and certainly my grandparents would have remembered, various wartime advertisements encouraging the average American to do his or her "part" during the second world war. Now we already know from reading Marx's Capital if we did not know it from Adam Smith or others that just such a transformation of nature and human relations is the heart of economic ordering. All the war shows, as if it had needed to be shown, is the calculation of the same order and the details of dependencies. The things one tends not to notice (that the amount of wood that will be needed to be managed in the Black Forest will be directly dependent upon the proliferation of journalism and propaganda and information tracts-pick your euphemism - so that, once again, rather than serving the lumber industry the woodsman is more accurately or actually serving the pamphlet or leaflet industry) and such superficially counter-intuitive relations were made more transparent in the years during and especially after the war. This way of commandeering the resources

\footnotetext{
${ }^{48}$ Ibid., 176. See on this Graeme Nicholson (1987), 171-187.

${ }^{49} \mathrm{I}$ adverted to this at the start and Philippe Lacoue-Labarthe underscores this as well when he recounts Heidegger's dispensation from university responsibilities in order to relocate his manuscripts to a safe place (in Messkirch), following "the (heavy) bombardment of Freiburg by English and American aerial forces." Lacoue-Labarthe (2004), 9.

${ }^{50}$ Many of us will have known, as I have known, urban scaffolds of the supposedly 'temporary' kind that have managed to endure for decades and decades...
} 
of the world for such further purposes "endures" and Jacques Ellul will take a leaf from Heidegger (and Friedrich Georg Jünger) to insist on what he calls the "autonomy" of technology and technique, noting that once it is set in motion, today's modern technology cannot be arrested. It might perhaps, and however unlikely, be diverted, but never simply stopped.

For Heidegger this setting up endures insofar as the set up is in turn imposed for the sake of other purposes, to which it is ordered (raw materials are raw materials for something, although and of course they can be stockpiled more generically within that same framework). Deployment or utilization "sets everything up in advance such that what is set up conduces to success ....But the resultant is arranged as success beforehand." ${ }^{51}$ And for Heidegger the resultant schema cannot but be self-reinforcing, and what is defined as "success," as he goes on to elaborate this, "is that kind of resultant that is itself allied to the production of further results. We call it ordering/requisitioning/com-portment [das Be-Stellen]." 52

For Heidegger, and if this were another paper, I might go in another direction, there is a difference between the kind of productivity of the village carpenter (we began by noting that Heidegger's father was one such) who might make or produce a table or who might for another purpose, make a coffin, a Todtenbaum, which itself would be destined, fitted not into the productive time and cares of the carpenter's industry but into another schema of another kind of temporality and care-here Heidegger uses the language of the cares or concerns of Being and Time-and that means into the constellation and intimate engagements of another world that is not the world of the manufacturer's workshop but the different world directionalities and setting of the "peasant's farm, the house and the land, the ones who dwell there, their kin, and the neighborhood." 53

There is no connection with any of that today, and intriguingly, we can cross the distance in time between Heidegger's 1950 lecture and 2013 without needing to change a thing. The "mechanized burial industry of the metropolis" 54 as Heidegger goes on to say by contrast does not lend itself to peasant rituals, themes or terminology. And if you want to see a French take on some of that, I recommend the climax of the wonderfully existentialist (not existential) 1986 film by Claude Berri, Jean de Florette when Jean (Gérard Depardieu in perhaps his most sympathetic role) is destroyed by his own techne (his dynamite) and his lack of techne (peasant experience) and above all by the failure of techne as what Aristotle named phronesis which would be knowing the difference between the two (that said, the technological critique of Jean de Florette is more Jacques Ellul than Martin Heidegger).

Comparing in a swift analogy the peasant's placing of his ox, positioning the animal in his traces just so, in order to advance the work he needs to get out of the ox, Heidegger writes that "Men and women must report themselves to a work service [Arbeitsdienst]. They are conscripted. They are met by a constellation [Stellen] that

\footnotetext{
${ }^{51}$ Heidegger (1994), 26.

${ }^{52} \mathrm{Ibid}$.

${ }^{53}$ Ibid.

${ }^{54}$ Ibid.
} 
places them, i.e., commandeers them." ${ }^{55}$ Heidegger thus goes into, as is his wont as we recognize this strategy from Being and Time to the later work on language, the meaning of the word, asking what das Ge-Stell means and and answering "to place, to position, to set" "so as to experience what comes to pass in that requisitioning and accountability through which a given stock arises and is thus a standing reserve.

Heidegger's analysis concerns civilian conscription, during and after a war on the most human level, whereby what is deployed are human beings as troops contra human beings as troops and of course and most lamentably contra those civilians who happen to be the enemy, and as part of that the requisitioning of whatever is at hand for the purposes of war. Like those summoned to do their part during war, Heidegger's point is that the approach is a total one, and there are parallels with Friedrich Georg Jünger, not unlike the parallels Walter Benjamin draws out in his reflection on the world of art in the age of technological reproduction with regard to the consequences of the first world war, when Benjamin cites the Futurist Manifesto of the Italian artisti, Marinetti in his own reflections. ${ }^{56}$ As Benjamin then goes on to explain the object contradiction that is the work of art as such:

the aesthetic of modern warfare appears as follows: if the natural use of productive forces is impeded by the property system, then the increase in technological means, in speed, in sources of energy will press toward an unnatural use. This is found in war, and the destruction caused by war furnishes proof that society was not mature enough to make technology its organ, that technology was not sufficiently developed to master the elemental forces of society. ${ }^{57}$

Benjamin continues by invoking what appears to be the fascist aesthetic, the aesthetics of pure politics: "Fiat ars-pereat mundus" and he explains this is as a direct consequence of technology and points out, too flatly for the nuanced sensibilities of a Horkheimer: "This is evidently the consummation of l'art pour l'art." 58 Invoking the cliché sublime converted here into the art-spectacular of a humanity converted from divine object to a subject absorbed with "its own annihilation as a supreme aesthetic pleasure," we are still far from thinking through the caesura, the space between the themes of his conclusion: "Such is the aestheticizing of politics, as practiced by fascism. Communism replies by politicizing art." ${ }^{\text {. }}$

To bring the point from a period after the first world war to Heidegger's time after the second world war (and still to this day, however we wish to understand 9/11 and the war on Iraq, Afghanistan, Syria and so on, and however we wish to

\footnotetext{
${ }^{55} \mathrm{Ibid}$.

${ }^{56}$ See the conclusion of Benjamin's "The Work of Art in the Technical Age of Reproducibility." I recommend the version (the second) of Benjamin's essay that appears in Benjamin (2008) despite the great advantages of Arendt's (1968) contextualization of the version that appears in the Shocken edition, because of the specific and useful secondary apparatus provided for this essay. Benjamin's discussion of photography including an allusion to war and to the origins of the technique, is varied, albeit without reference to Benjamin, in Friedrich Georg Jünger (1946).

${ }^{57}$ Benjamin (2008), 42.

${ }^{58}$ Ibid.

${ }^{59}$ Ibid.
} 
understand the Keystone Pipeline to the US coast or the relentlessly stupid use of fracking), Heidegger points to these everyday circumstances and these everyday ontic consequences when he observes that "a tract of land is coopted, namely for the coal and ore that subsists in it." 60

This notion of cooption and it should be clear here that Heidegger is talking about newly requisitioned tracts, newly requisitioned by the Nazis and then again in the postwar era, rather than offering some merely nostalgic musings in praise of the farmer's traditional field. For us today and to be sure, all this is a matter of 'development,' one thereby sets up a coal or another mining industry (we can add, if we like, that just such cooption sets up a fracking industry for extracting natural gas, requiring the use of vast quantities of fresh water, yet further evidence of the 'perfection' of technique in Jünger's sense as the engineering science of fracking requires pure rather than 'recycled' water, which is then an industry, paralleling Heidegger's awful agricultural example, that is/becomes an industry for the production of contaminated aquifers along with the production of contaminated soil and of course-because we are talking about gas-the production of polluted and poisoned air). In this way or "through such requisitioning [Bestellen] the land becomes a coal reserve, the soil a mineral deposit." Immediately contrasting this with the farmer's practice with respect to the land and to nature, as a kind of allowing, this is the meaning of Gelassenheit, "the crops to grow as nature itself allows," ${ }^{61}$ Heidegger thus seeks to raise the question concerning the difference made by modern technology in this contrasting opposition, and here we need the entire quote

In the meantime, however, even the tending of the fields [die Feldbestellung] has gone over to the same re-quisitioning [Be-Stellen] that imposes upon the air for nitrogen, the soil for coal and ore, the ore for uranium, the uranium for atomic energy, and the latter for destruction on command. ${ }^{62}$

The lineage traced is that of modern technology and the efficiency of a technological world order. Everything is regarded, and we know this, we take this for granted, for the purposes of development, by which we mean if we are doing development studies: technological orderability or usability in the same schema or setup. Everything fits into this frame and there is no outside. If Marx saw the dynamic of the machine as reducing the needed labor of the worker to no more than an appendage, a fitted extra, and thus the stupidification of the human as a necessary part of capital and its mechanized deployment, as part of the complex relation of the human being to nature within the sane very material dialectic, Nietzsche himself points to a similarly coordinate structure when he argued that we humanize nature and everything else by cutting it to our measure (these are the "bounds" of sense in Nietzsche's articulation of the critique of reason in the third book of The Gay

\footnotetext{
${ }^{60}$ Heidegger (1994), 26-27.

${ }^{61}$ Ibid., 27.

${ }^{62}$ Ibid.
} 
Science) but also as he goes on in On the Genealogy of Morals to highlight the numbing of the mind that, as he teased, is called "the blessing of work." 63

Still it is one thing again to guess at the brutalizing direction of technology, and Nietzsche's language of the "God of machines and smelting pots," ${ }^{4}$ seems to capture the high regard we have for the priests of the same god, the engineers and technicians and indeed the scientists and theorists of all kinds. By contrast, and this is where the practical level, the ontic matters of the ordinary come into play, it is quite another thing again to live through the pains of such a transformation of the world in the image of technology, as Heidegger lived through this transfiguration, through two world wars, even if one could argue that we are today still, as we are, and not that we give it a thought, living through wars all the same. For the work of this transfiguring force is now largely consummate and we ignore, we do not live through, the wars we have consistently been fighting. If Heidegger could ask if the victims relegated to annihilation camps 'died' or if (and let us not forget that for Heidegger the word and the meaning of the word in each case makes all the difference) they did not much rather and simply 'perish'? The word he uses, the technical term as historians also use it, is liquidation. And whatever fate that is, what it is not, what does not have a chance to touch it (and those so condemned are bereft of exactly this on Heidegger's account) is death: a death, and above all, not one's own death: a death that one might take up, or and this is pure luxury, as we see, refuse to appropriate, refuse to live. The inauthentic death is also what one does not die in such camps.

For our part, we also ignore, as Baudrillard argued that we should not but that we cannot but fail to see, the political realm, which "political" we take to be all about what the journalism cum culture industry serves up to us. ${ }^{65}$ Baudrillard's term was 'integrated reality,' which we ought today rename embedded reality, all the while unaware of what really happened to close down the OWS movement (New York City, after all, is where it began) and it is worth noting that I offered an earlier talk scheduled during the events of the original Occupy Wall Street ${ }^{66}$ to the same group at the New School that initially invited me to give the talk on which the current essay is based. Here what matters with this detail and allusion to "real life" is that we scholars and citizens, journalists and consumers barely notice today that Wall Street is no longer "occupied," and we do not bother to attend to such routine and

\footnotetext{
${ }^{63}$ Nietzsche (1980), Vol. 5, 382. The full citation is useful: "Viel häufiger als eine solche hypnotistische Gesammtdämpfung der Sensibilität, der Schmerzfähigkeit, welche schon seltnere Kräfte, vor Allem Muth, Verachtung der Meinung, »intellektuellen Stoicismus « voraussetzt, wird gegen Depressions-Zustände ein anderes training versucht, welches jedenfalls leichter ist: die machinale Thätigkeit. Dass mit ihr ein leidendes Dasein in einem nicht unbeträchtlichen Grade erleichtert wird, steht ausser allem Zweifel: man nennt heute diese Thatsache, etwas unehrlich, »den Segen der Arbeit «.

${ }^{64}$ Nietzsche (1980), Vol. 1, 114f. Nietzsche is here, in his first book, coordinating the allure of a metaphysical comfort with the ideal of an "earthly consonance."

${ }^{65}$ See Baudrillard's (2005a).

${ }^{66}$ The earlier talk in question combined a lecture originally given in Dublin and a lecture entitled "Requiem" given at Boston College. The first lecture is forthcoming: as Babich (2013a).
} 
such ontic details unless a Facebook post is sufficiently annoying to compel us to do so, likewise we are oblivious to our torture of our prisoners as we still detain them in Guantanamo, all that after electing a president on the explicit mandate that such detention centers follow the rule of law (hasn't happened and we elected that same president again, anyway), and we certainly think nothing of the overkill (tanks in the street, martial law, the complete shutdown of the town) required to catch two college students in Boston (called terrorists), killing one and leaving another at least initially unable to speak (Aristotle's Nicomachean Ethics goes on at length about the fortune of that circumstantiality): we as a media populace followed the manhunt in Boston with the avidity usually reserved for a contest on American Idol. Politics for us, as Baudrillard wrote again and again, alas with Gallic impenetrability, is all about the issues that are presented to us as news.$^{67}$ History may well tell a different story, but this is doubtful, and this too was also Baudrillard's point, Kittler's too when he could turn his attention from his Greeks and other dissipations. ${ }^{68}$ After everything is digitized which means to be sure, after every record can be infinitely revised or changed at will - according to whoever's whim, whatever, the point to be remembered (no one will be able to make it) is that no one will be able to demonstrate/prove/notice the effects or consequences of such limitless alterability (this is the real meaning of the Leibnizian difference that makes no difference).

Yet one should be skeptical: we remain in need of a critical theory for our times and the current practitioners of the same, be they in Frankfurt or New York or Chicago, have fallen silent on anything that resembles critique. And these titulary practitioners control all the journals (Critical Theory, Constellations, etc.) and they control all the fellowships and they control all the books that are published in supposedly respectable presses. And did I say professorial posts too? No, because I did not have to: this goes without saying.

Repeated twice in these two core lectures, Das Ge-Stell and Die Gefahr, which may now be taken as the locus of Heidegger's abyssal politics, is (again) his un-speakable, claim about death and technology and we have heard about this and about its untenability all our intellectual lives. The most incendiary locus for this twice-repeated provocation might be as expressed in Das Ge-Stell. This is the locus that one scholar quoted out of context after gaining access to the thennot-yet published text (this is the fun of plundering archives, not that there are all that many chances for those doing archival work to do comparable things), after promising not to quote it out of context. But by breaking a promise (and one makes such promises in order to break them, as Kant tells us, namely as we seek to gain an advantage and because we know or tell ourselves that without just that false promise, breaking in our unsovereign mouths, as Nietzsche says calling us windbags, even as we utter it [this is the point of the aphorism on the Nietzsche's 'sovereign individual at the start of the second part of On the Genealogy of

\footnotetext{
${ }^{67}$ See Baudrillard (2005b) but see too one of his final essays available in English, Baudrillard (2009).

${ }^{68}$ This is not a matter of being for (or against) the media as it is also not a matter of being for or against technology.
} 
Morals]), that same advantage is denied us. The advantage won by Wolfgang Schirmacher yielded the quote that generated a small book industry, large if you count Wolin, huge if you count Tom Rockmore's books, which is of course the Heidegger scandal, beginning with Levinas, Lacoue-Labarthe, Derrida, Habermas too. ${ }^{69}$ In fact Heidegger makes two similar declarations, but the first one is the most notorious and it runs as follows

Agriculture is now a mechanized food industry in essence the same as the production of corpses in the gas chambers and extermination camps, the same as the blockading and starving of countries, the same as the production of hydrogen bombs..$^{70}$

All of these things, for Heidegger, hence our horror, in essence: the same. For Heidegger this sameness is so because it cannot but be so: everything is drawn into the gyre, the "centre cannot hold" indeed we need the whole array of Yeats' rebuke of historicity and modern fatefulness or futurity because the essence of modern technology in our world happens to remain as that which Heidegger saw it as being, and to which insight into that which is, he sought to call our attention.

The setting upon of modern technology is critical, crucial, indispensable for Heidegger and that is how he can utter such an offensive comparison: for him modern technology is all about such equations, such calculations, such reductions. Thus we noted with respect to a different kind of land-use, switching agrarian land over, opening it up, literally so, to the coal industry, that Heidegger writes that with that the coal itself (he has the Rilkean poem to the wealth of the kings slumbering in the mountains in his mind), is ordered, set upon: "challenged forth for heat, as the ground is challenged forth for coal." Here the constellating point in question will be that heat itself, today we would say energy,

is already set to set up steam, the pressure of which drives the turbines, which keep a factory productive, which is itself ordered to set in place machines that produce tools by means of which again, machines are set to work and maintained. ${ }^{71}$

The subsequent and for environmental studies indispensable reflective array to which Heidegger then turns only offers an elaboration of this point:

The hydroelectric plant is placed in the river. It imposes upon it for water pressure, which sets the turbines turning, the turning of which drives the machines, the gearing of which imposes upon the electrical current through which the long-distance power centers and their electrical grid are positioned for the conducting of electricity. The power station in the Rhine river, the dam, the turbines, the generators, the switchboard, the electrical grid - all this and more is there only insofar as it stands in place and at the ready, not in order to be there (presence), but to be positioned, and indeed solely to impose upon still others. ${ }^{72}$

\footnotetext{
${ }^{69}$ There is no shortage of discussions of the same: I list this literature myself in several essays, as do many, many, many others, but see, for a start, Babich (2009), 227-243 as well an earlier essay, on Babich (1992), 83-106.

${ }^{70}$ Heidegger (1994), 27

${ }^{71}$ Ibid.

${ }^{72}$ Ibid.
} 
Heidegger could not understand the engineering array or constellation any better, maybe this what our culture industry means when it praises German engineering to this day, usually in a Volkswagen ad or just an advertisement for a coffee machine.

Heidegger goes on to notice that this includes human being in deep ways and he speaks of the machination, "mechanization of the human," "the human being is ordered by and for the requisitioning." 74

All this can seem to be taking us rather far afield, and as Das Ge-Stell serves as prelude to Heidegger's lecture on Die Gefahr, we turn to consider, as promised, Heidegger's reflection on the $G e$.

\begin{abstract}
We name the collection of mountains [die Versammlung der Berge] that are already gathered together, united of themselves and never in retrospect, the mountain range [das Gebirge]. We name the collection of ways according to which we are disposed to such and such, and can feel ourselves so disposed, our frame of mind [das Gemut]. We now named the self-gathered collection of placing, setting [das Stellens], wherein everything orderable essences in the standing reserve, das Ge-Stell. ${ }^{75}$
\end{abstract}

Here for Heidegger everything is harrowed, harvested, arranged, disposed to standing reserve and industry, and in this sense he can claim that "das Ge-Stell is the essence of technology."'76

\title{
1.1 Die Gefahr/The Danger
}

As is typical for Heidegger, as we already know if we have learned to follow the rhetorical didacticism that characterizes the strategic articulations of Being and Time, Heidegger repeats the moves he introduces in Das Ge-Stell in the following lecture Die Gefahr, and he does so in a thoroughly scholastic fashion. To be sure, the reason that Jack Caputo and others can undertake to read Heidegger and Aquinas together is because of Heidegger's scholastic formation, not unlike Kant's own formation and indeed and to be sure as Heidegger admires Kant throughout his life. ${ }^{77}$ Here Heidegger closes his fourth lecture on the turn by invoking Kant on the ultimate practical question, the ground of being qua being and as such: that would be God even for the godless, as (the believing) Kant himself is usually blamed for being the instigator of nihilism, at least according to Fichte and Jacobi. ${ }^{78}$ For his part, Kant was already writing in a godless time, after Newton, after Laplace's

\footnotetext{
${ }^{73}$ Ibid., 28.

${ }^{74}$ Ibid., 29.

${ }^{75}$ Ibid., 32,

${ }^{76}$ Ibid., 33.

${ }^{77}$ See on Heidegger and Aquinas Jack Caputo's often cited study (1982). See on Heidegger and Kant, as an overview, Daniel Dahlstrom (2010). Willi Goetschl (1994) offers a useful background for the (very differently) hermeneutically contextualizing framework to which I am adverting here.

${ }^{78}$ This is complicated even beyond the constellations Freerick Beiser has tracked in his work. I discuss this, citing Beiser and others, in some of my footnotes to Babich (2010b), 231-256.
} 
Mécanique Céleste (finished in 1725, Kant would draw upon this for his own nebular hypothesis in 1755), and Heidegger's schoolman's (and hence classically didicatic strategy) is simply to tell us what he is doing and then to do so and then to reprise what it is that he has done..$^{79}$ In this sense "The Turn" inevitably has nothing to do with the way typical Heideggerians seeking to divide their bit of Heidegger into something manageable tend to speak of it, as if there might be a change in Heidegger's thinking (Heidegger as we know is famous for saying that a thinker thinks only one thought), and we have already noted that where we might need to locate such a change or turn we do not need to wait for these lectures for it is already noted in Heidegger's Letter on Humanism (and it is of course albeit in a secret, esoteric, or unpublished way already present in the Beiträge). ${ }^{80}$ In the Letter on Humanism Heidegger declares that "everything is reversed," ${ }^{81}$ or turned around, but scholars will find such a translation or reflexive turning in his Introduction to Metaphysics, or indeed in the 1935 lectures on The Origin of the Work of Art, which are themselves, as they have to do with nothing other than the Greek notion or meaning of techne, likewise indispensable for the four lectures on technology.

The focus on calculation with which Heidegger ends his lecture on Das Ge-Stell is replaced with a reflection on worlding in terms that we recognize as the terms of the fourfold, and which if we keep Heidegger's reflections on the happening or event of truth in his lecture on the artwork highlights "worlding" coming to presence:

World is the fourfold of earth and sky, divinities and mortals. In the uniting whole of its presence, the mirrorplay of the fourfold guards everything that thingingly presences and absences between the four. ${ }^{82}$

As we also recognize from Being and Time, Heidegger gives nothing - he is not a Hegelian, as it happens, for nothing - without simultaneously also taking it away. Thus after indicating the importance of the safeguard, of sheltering (and we recall that this is at the heart of his reflections on physis), Heidegger observes that "The world still refuses itself as world. World still withdraws into the concealment proper to it." ${ }^{83}$ The difficulty for any discussion here as we recognize this immediately from our familiarity with Being and Time but also from our rather persistent unfamiliarity with Heidegger's 1930 Essence of Truth, is that we are confounded by lighting and concealing, showing hiding, aletheiallethe.

The problem as Heidegger writes here, nicely concisely, is that "aletheia does not properly guard itself in its own essence it lapses into concealment, lethe,

\footnotetext{
${ }^{79}$ See on this: Babich (1993), 239-260.

${ }^{80}$ See for an important and subtle discussion of this complex theme, Richard Polt (2006) and see too in this context Babich (2010c), 397-415.

${ }^{81}$ Heidegger (1977c). See for a discussion of this politicized political context along with further references, see Babich (2013c).

${ }^{82}$ Heidegger (1994), 48.

${ }^{83}$ Ibid., 49.
} 
aletheia falls into forgetfulness." ${ }^{" 84}$ By this means to be sure, Heidegger both introduces the danger qua danger as well as recuperating his own reflection on the sheer forgottenness of being which he has in the interim (as we know from the Beiträge) begun to write as Seyn.

What Heidegger here calls the "refusal" of world, which he expresses as the Ereignis, happening or event, also sometimes rendered as "appropriation" "Diese Ereignis besteht darin das Welt als die Wahrnis des Wesens des Seins sich verweigert." ${ }^{85}$ World thus refuses itself as the preserver, guardian, harborer of the essence of Being. Heidegger now offers us two references to temporality, one to the then-current dispensation of world-affairs, as the "unfolding of planetary totality," observing as the defeated party to the previous contest for world-domination (i.e., the Germans as the losers in the second world war) could not but be, however awkwardly, perfectly placed to observe that "the modern battle for mastery of the earth is concentrated upon the position of the two contemporary 'world' 'powers." (51) This is complicated to the extent that Heidegger coordinates the refusal of world as manifest as eventuated via or through the defenseless of the thing noting that in this relation one to another they are "the same if to be sure not the identical." (Ibid.) But the distinction is not idle for Heidegger: "the same [das Selbe]," he will go on to emphasize "is never the identical [das Gleiche]." (52) At this point what is at issue for Heidegger is the refusal of world and the vulnerability of the thing in the prevailing turn of the set up he has analysed as modern technology. Everything but everything is presented as the ordered 'items at hand' or standing currency of standing reserve. "Ge-Stell" he writes adumbrated in this play on standing reserve "is" this disposition and is accordingly "the essence of modern technology." (51) But this conjunction is one of the moment, the present time, the insight is into that which is, in its immediacy, thus Heidegger goes on to observe that this holds not 'as such' or 'from all time' but very literally 'here,' just to the extent that it is here and now that we find that the "oblivion of the essence of being is consummate." In the same way, and now we see why so many commentators inevitably turn here to a reflection on The Origin of the Work of Art," Heidegger also writes that "World and Ge-Stell are the same." (52)

Calculation, a concern for Heidegger from the start, both in his reflections on truth in Being and Time as in the Essence of Truth, as in his reflections on "Science and World Picture," all originating from his original and enduring interest in science and his interest, inevitable for anyone who works on Dilthey's account of history but also anyone in philosophy who is both a contemporary as Heidegger was, roughly speaking here, as you are whether you like it or not as students a contemporary of my ancient self just as I was when I was a 23 year old student when I met first met William Richardson as well as being the contemporary of my even more ancient teacher, the same Gadamer at 80 , so similarly was Heidegger a contemporary of Max Weber as well as from its outset to its flourishing with the same Rudolf Carnap we already began by noticing, and beyond to its current

\footnotetext{
${ }^{84}$ Ibid.

${ }^{85}$ Ibid., 50-51.
} 
world-dominion within philosophy proper in so-called analytic philosophy, logical positivism, the issue of values was for Heidegger a matter of weighting and weighing the same. We cannot count the time of life with a clock, we cannot calculate it at all. Thus Heidegger writes, playing on the banality of banality, the indifference of the diffident-Alles gilt gleich — same old, same old, we might say. (52)

If a further discussion of calculation cannot here be considered, what is important to note is that the same preface, the Ge-that remains at issue, is also to be considered in the danger, die Ge-fahr. Two coordinate and even nested claims make this clear: "The essence of technology is the Ge-Stell. The essence of the Ge-Stell is the danger." (54) In effect, it is the Ge-Stell as such, the enframing, the set up that "sets after the truth of the essence of being with forgetfulness." (53) This harrying, harrowing is Heidegger's "pur-suit'-here the word is not Gestellen, but Nachstellen. For Heidegger, as he writes, in "Old High German, to pursue is called fara." (53) The Ge-Stell, the set-up, or the en-framing "gathered in itself as pursuit is the danger [Das in sich gesammelte Stellen als Nachstellen ist die Gefahr]." (53) What is key here just as in the folded, referentiality or integral orderedness of the Ge- in Ge-Stell, is the gathered in itself of the pursuit in question, as the danger. The Hegelian move here brings us him to reflect "that Beyng (Being or Sein spelled with a y, in an ancient mode, as Seyn) is the danger. Beyng is unqualifiedly in itself, from itself, for itself" (can't get more Hegelian than this) "the danger. As this pursuit, which pursues its own essence with the forgetting of this essence"-here, again, we recognize aletheia- “beyng as beyng is the danger." (53)

Here Heidegger's definition of the danger summarizes the lectures to this point:

The danger is the collected pursuit [sich in sich versammelte Stellen als Nachstellen] as which en-framing/set up [als welches das Ge-Stell] in the guise of unguardedness of the thing, pursues the self-refusal of world with the forgetting of its truth." (54)

For Heidegger, and note that our reading through an English language lens challenges us, we are left to reflect that we do not experience [Erfahren] the danger as danger." (55) It is in this context that Heidegger presents the currency of need and desperation, that is: he lists a litany of death, as indeed of pain that is to say suffering, and also of poverty, all and each as what confronts us and at the same time manages not to touch us, leaving us unmoved, unchanged, in a terrifying sense. The phenomenon to which Heidegger refers here continues to this day as we well know, all you have to do is read the paper, check Facebook and note how many awful things and then note how little any of those things affect you really or at all: talk about the oblivion of being as much as you like.

For Heidegger in the midst of extraordinary need and desperation, and from 1945 onward, certainly unabated by 1949 in Germany, that is then pretty much everywhere in that defeated land, precisely to the extent that the businessmen and city fathers to whom Heidegger spoke in Bremen, just to the degree that they did indeed address this need and that need, as people organized to respond to devastations in this way and that, remedying problems in this way and that, that precisely in the midst of "ameliorating pain and tending to neediness" (55-56) what remains critical for Heidegger is that precisely while so engaged "one does not attend to the need." (65) Heidegger has 
a name for this — which he explores already in Being and Time, errancy, die Irre ${ }^{86}$ It is our amazing ability not to be where we are, which (remember that we are for Heidegger Dasein), only means that we are not who we are. In this sense, Heidegger observes here, „Das Wesen der Irre beruht im Wesen des Seyns als der Gefahr.” [The essence of errancy subsists in the essence of Seyn as the danger.] (56)

This same errancy plagues us when in the same paradoxical sense in which the paradox of neediness prevails such that we all have needs, we all have our desperations, but we do not in midst of our worries actually because we cannot begin to attend to needfulness as such. In the context of this reflection on death, suffering or pain and neediness or needfulness and all the heedlessness of the same in the midst of an abundance of the same, we encounter the second version, or variant upon Heidegger's seeming insensitivity (which we now see to be an insensitivity in his words on insensitivity as we hear him). This locus, situated in postwar needfulness, is the most grim, and it is perhaps because of its time, harsher in tone than Heidegger's more popular (it was a radio) lecture "Building, Dwelling, Thinking," broadcast in 1951 with its own respective (and indeed more hopeful) reflections on need and needfulness. Here in The Danger we read:

Hundreds of thousands die in masses. Do they die? They succumb. They are put down. Do they die? They become inventory items of a standing reserve for the fabrication of corpses. Do they die? They are unremarkably liquidated in annihilation camps. And even without such - millions now in China, end pathetically in starvation. (56)

In this context, it can be argued that the Heidegger of Being and Time thereby reclaims his own reflection on what he had offered for reflection on death, that is being-towards-death, as this specifically characterizes human beings in their mortality, as beings concerned with their being and aware of their vulnerability in being in the mode (this is high Heidegger, esoteric Heidegger) of disattending, flight, forgetfulness of being.

Death shelters [birgt] the essence of being. Death is the highest re-fuge [Gebirg] of the truth of being itself, the refuge that in itself shelters [birgt $]$ the concealment [Verborgenheit] of the essence of being and gathers together the sheltering [bergung] of its essence.... To be capable of death in its essence means to be able to die. (Ibid.)

But for Heidegger: "The human is not yet the mortal." (56) Since much of Heidegger's project in Being and Time was all about explaining life in terms of living and in terms of the vanity of mortal beings who take themselves to be immortal, as we do, proximally and for the most part, what fascism took from its others was what made them human, even in its constant, as it is pretty much always, default.

Here I want to emphasize as this essay moves toward its conclusion that the same technique, the same modus, asks us to attend to Heidegger's very overtly hermeneutic phenomenology (he is not-despite the Spiegel's sensationalist insistence on the same, an insistence shared by numerous junior college professors - an 'existentialist') with respect to our obliviousness, thoughtlessness. "Immeasurable suffering shifts

\footnotetext{
${ }^{86}$ Die Irre, or errancy has been a lasting concern for William Richardson as one can read beginning with his (1993). And see too the contributions to Babich (1995).
} 
and surges across the earth. But the essence of pain conceals itself. ...Everywhere we are besieged with countless and boundless suffering. We however are not pained [schmerzlos], we are not appropriated to the essence of pain.'(57)

We are not pained and today there is more of this un-moved, painlessness than ever. Who bothers to watch animal rights videos, if one ever did, who is really concerned about the plight or fate (pick any word you like) of the Palestinians, the Syrians, the Nigerians, etc. and etc. and etc.?

Death, the mountains of Seyn, pain, the schema of Seyn, poverty, the liberation into the ownership of Seyn, are features allowing the danger to be remarked, that needfulness is excluded in the midst of the greatest neediness, that the danger is not as the danger allowing the danger to be noted. (Ibid.)

We are unpained, we do not sense what is all around us, as Heidegger who will turn in his last essay on the turn to language by which as he explains he means our need to lay claim to it. And today, I would argue, we are no further advanced: we still need to recall Hölderlin's warning to us, whether as scholars of being or of language as all those who have lost their tongues in foreign (and native) lands.

Here Heidegger seeks to differentiate his reading from those who contend that "technology is the catastrophe of the modern world" (58) and so on. For Heidegger it is already problematic to offer a critique of technology in a technological age, no matter in what voice one seeks to do so. The point here is that whether one praises or damns it, "at the same time one greedily scurries after the latest technological advance, perhaps one cannot but run after it in this way." (58) Yet to this same extent "judgment and inclination with respect to technology contradict themselves and the same contradiction is taken as objection." (Ibid.)

Heidegger's perhaps best known claim that the "essence of technology is itself nothing technological" (60) remains, as he reprises it in the final lecture, The Turn, almost in the same words, arguing that everything that is "merely technical" can "never attain to the essence of technology" (Die Kehre, 76). We do not grasp and hence cannot begin to articulate what he calls the "insight into that which is," to the extent that we do not even ask after the import of the times as they unfold around us.

"But," for Heidegger, "we do not yet hear, we, under the dominion of technology, whose hearing and seeing decay through radio and film." (Die Kehre, 77) Here we can and should add the internet (why on earth not?), but for Heidegger what we do not yet hearken to or see is occluded not simply by way of our thuggishness or inattention: "The constellation of beyng is the refusal of world as world."

If earlier, Heidegger had responded to a question on humanism by recalling a related request for a contribution to ethics by distinguishing between the modern notion and the ancient Greek sense of the same, he also took care to be blunt about the circumstances of such thought, as we have already referred to his earlier lecture on poverty. For Heidegger as he goes on to note in his letter to a former enemy in 1946, philosophizing or thinking "about being shattered is separated by a chasm from a thinking that is shattered." ${ }^{87}$

${ }^{87}$ Heidegger (1954/1977c), 223/340. 
Maybe, and in the spirit of the small, the slight recommendation, we might begin, after all this time, to take up Heidegger's more complex question. That is his question concerning the "world, worlding," as this would be "the nearest of everything that nears," now heard as we perhaps should always have heard it as the question of Ereignis, that is in terms of what Heidegger called Eigentlichkeit: appropriation appropriated as it were, qua the "ownership of appropriation." (Ibid.) For as we also know, from the start, what Heidegger meant by Eigentlichkeit was never 'authenticity' (and it is easy to remember that German has a term for authenticity, die Authenticität) but owned ownedness, appropriated appropriation. ${ }^{88}$

Ereignis.

\section{References}

Adorno, Theodore. 1945. A social critique of radio music. The Kenyon Review 8(2): 208-217.

Adorno, Theodore. 2006. In Adorno, Current of music, ed. Robert Hullot-Kentor. Frankfurt am Main: Suhrkamp.

Anders, Günther. 1956. Die Welt als Phantom und Matrize. Philosophische Betrachtungen über Rundfunk und Fernsehen. In Anders, Die Antiquirtheit des Menschen, Erster Band. Über die Seele im Zeitalter der zweiten industriellen Revolution, 97-214. München: Beck.

Arendt, Hannah. 1968. Introduction. In Walter Benjamin, Illuminations: Essays and reflections, 1-58. New York: Schocken Books.

Babich, Babette. 1992. Heidegger's Silence. In Ethics and danger: Currents in continental thought, ed. Charles Scott and Arleen Dallery, 83-106. Albany: State University of New York Press.

Babich, Babette. 1993. A musical retrieve of Heidegger, Nietzsche, and technology: Cadence, concinnity, and playing brass. Man and World 26: 239-260.

Babich, Babette (ed.). 1995. From phenomenology to thought, errancy, and desire : Essays in honor of William J. Richardson, S.J. Dordrecht: Kluwer.

Babich, Babette. 2003. On the analytic-continental divide in philosophy: Nietzsche's lying truth, Heidegger's speaking language, and philosophy. In A house divided: Comparing analytic and continental philosophy, ed. C.G. Prado, 63-103. Amherst: Humanity Books.

Babich, Babette. 2009. From the ethical alpha to the linguistic omega: Heidegger's anti-semitism and the question of the affinity between ancient Greek and German. In Words in blood, like flowers: Philosophy and poetry, music and eros, 227-243. Albany: State University of New York Press.

Babich, Babette. 2010a. Towards a critical philosophy of science: Continental beginnings and bugbears, whigs and waterbears. International Journal of the Philosophy of Science 24(4): 343-391.

Babich, Babette. 2010b. Ex aliquo nihil: Nietzsche on science and modern nihilism. American Catholic Philosophical Quarterly 84(2): 231-256.

Babich, Babette. 2010c. Heideggers Widerstand. Nietzsche lesen als eine »Konfrontation« mit dem Nationalsozialismus. In Heidegger und der Nationalsozialismus II. Heidegger Jahrbuch 5 , ed. Holger Zaborowski and Albert Denker, 397-415. Freiburg im Briesgau: Alber.

Babich, Babette. 2011. An Impoverishment of Philosophy. Purlieu: Philosophy and the University (1): 37-71.

\footnotetext{
${ }^{88}$ This essay was originally presented at the New School at the invitation of Christopher Merwin to the New York Phenomenology Group on 25 April 2013. I am grateful to Chris Merwin, Tracy Strong, and to the participants at that meeting for an especially engaging discussion.
} 
Babich, Babette. 2012. Heidegger's philosophy of science and the critique of calculation: Reflective questioning, Gelassenheit, life. In Heidegger on science, ed. Trish Glazebrook, 159-192. Albany: State University of New York Press.

Babich, Babette. 2013a. The Hallelujah effect: Philosophical reflections on music, performance practice and technology. Surrey: Ashgate.

Babich, Babette. 2013b. The 'New' Heidegger. In Heidegger in the 21st century, ed. Tziovannis Georgakis and Paul Ennis. Frankfurt am Main: Springer. Forthcoming.

Babich, Babette 2013c. Shattering the political or the question of war in Heidegger's Letter on Humanism. Proceedings of the Heidegger circle 2013. Convenors: David Pettigrew and Rex Gilliland. New Haven: University of Southern Connecticut, 25-49.

Bast, Rainer A. 1986. Der Wissenschaftsbegriff Martin Heideggers im Zusammenhang seiner Philosophie. Stuttgart: Frommann-Holzboog.

Baudrillard, Jean. 2005a. The Intelligence of Evil or the Lucidity Pact. Trans. Chris Turner. London: Bloomsbury.

Baudrillard, Jean. 2005b. Simulacra and Simulation. Trans. Sheila Faria Glaser. Ann Arbor: University of Michigan Press.

Baudrillard, Jean. 2009. Why Hasn't Everything Already Disappeared? Trans. Chris Turner. Chicago: Seagull.

Benjamin, Walter. 2008. The Work of Art in the Age of Its Technological Reproducibility, and Other Writings on Media. Trans. Edmund Jephcott and Harry Zohn. Cambridge: Belknap Press of Harvard University Press.

Bernays, Edward. 1928. Propaganda. New York: IG Publishing.

Caputo, John. 1982. Heidegger and Aquinas: An essay on overcoming metaphysics. New York: Fordham University Press.

Caputo, John. 1986. Heidegger's philosophy of science: The two essences. In Rationality, relativism, and the human sciences, ed. Joseph Margolis et al., 43-60. The Hague: Nijhoff.

Celan, Paul. 1980. Poems. Trans. Michael Hamburger. Persea: New York.

Celan, Paul. 2000. Gesammelte Werke. Frankfurt am Main: Suhrkamp.

Chickering, Roger. 2007. The great war and urban life in Germany: Freiburg, 1914-1918. Cambridge: Cambridge University Press.

Dahlstrom, Daniel. 2010. The critique of pure reason and continental philosophy: Heidegger's interpretation of transcendental imagination. In The Cambridge companion to Kant's critique of pure reason, ed. Paul Guyer, 380-400. Cambridge: Cambridge University Press.

Der Spiegel. 1950. Heidegger. Rückfall ins Gestell. 14: April 6.

Figal, Günther. 2006. Einführung. Heidegger Lesebuch. Frankfurt am Main: Klosterman.

Friedman, Michael. 2000. A parting of the ways: Carnap, Cassirer, and Heidegger. Chicago: Open Court.

Gadamer, Hans-Georg. 1995. Philosophische Lehrjahre. Eine Rückschau. Frankfurt am Main: Klostermann.

Gethman, Carl Friedrich. 1991. Der existentialen Begriff der Wissenschaft. Zu Sein und Zeit §69b. In Lebenswelt und Wissenschaft: Studien zum Verhältnis von Phänomenologie und Wissenschaftstheorie, ed. Carl Friedrich Gethman, 181-209. Bonn: Bouvier.

Glazebrook, Trish. 2012. Why read Heidegger on science? In Heidegger on science, ed. Trish Glazebrook, 159-192. Albany: State University of New York Press.

Goetschl, Willi. 1994. Constituting Critique: Kant's Writing as Critical Praxis. Trans. Eric Schwab. Durham: Duke University Press.

Gordon, Peter. 2012. Continental divide: Heidegger, Cassirer, Davos. Cambridge: Harvard University Press.

Guzzoni, Ute. 2012. Gelassenheit: Beyond technoscientific thinking. In Heidegger on science, ed. Trish Glazebrook, 193-204. Albany: State University of New York Press.

Heelan, Patrick Aidan. 2012. Carnap and Heidegger: Parting ways in the philosophy of science. In Heidegger on science, ed. Trish Glazebrook, 113-130. Albany: State University of New York Press. 
Heidegger, Martin. 1951. Bauen Wohnen Denken, Westdeutsche Rundfunks, Cologne. CD edited by Eduard Führ and the Waxman Verlag.

Heidegger, Martin. 1954. Über den Humanismus. Brief an J. Beaufret. Bern: Francke.

Heidegger, Martin. 1959. Introduction to Metaphysics. Trans. Ralph Manheim. New Haven: Yale University Press.

Heidegger, Martin. 1962. Die Technik und die Kehre. Pfullingen: Neske.

Heidegger, Martin. 1962 [1927]. Being and Time. Trans. John Macquarrie and Edward Robinson. New York: Harper \& Row.

Heidegger, Martin. 1971. Poetry, Language and Thought. Trans. Albert Hofstadter. New York: Harper.

Heidegger, Martin. 1977a. The question concerning technology. Trans. William Lovitt. In: Heidegger, The Question Concerning Technology and Other Essays, 3-35. New York: Harper.

Heidegger, Martin. 1977b. The Question Concerning Technology and Other Essays. Trans. William Lovitt. New York: Harper \& Row.

Heidegger, Martin. 1977c. The letter on humanism. Trans. Frank A. Capuzzi. In: Heidegger, Basic Writings. New York: Harper \& Row.

Heidegger, Martin. 1978a [1954]. « Die Frage nach der Technik ». In Heidegger, Vorträge und Aufsätze, 9-40. Pfullingen: Neske.

Heidegger, Martin. 1978b [1954]. «Wissenschaft und Besinnung » In Heidegger, Vorträge und Aufsätze. 41-66. Pfullingen: Neske.

Heidegger, Martin. 1991. Heidegger, Nietzsche. Volumes Three and Four. Trans. Joan Stambaugh and Frank A. Capuzzi. San Francisco: Harper.

Heidegger, Martin. 1994. Einblick in das was ist. In Heidegger, Bremer und Freiburger Vorträge, 1-77. GA 79. Frankfurt am Main: Klostermann.

Heidegger, Martin. 1998. The letter on humanism. Trans. Frank A. Capuzzi. In Heidegger, Pathmarks, ed. Will MacNeill. Cambridge: Cambridge University Press.

Heidegger, Martin. 2003. Letter to Richardson. In William J. Richardson, Heidegger: Through phenomenology to thought. New York: Fordham University Press.

Heidegger, Martin. 2004 [1945]. la pauvréte (die Armut). Trans. Philippe Lacoue-Labarthe and Ana Samardzija. Strasbourg: Presses Universitaires de Strasbourg.

Heidegger, Martin. 2012. Bremen and Freiburg Lectures. Insight into that Which is and Basic Principles of Thinking. Trans. Andrew J. Mitchell. Indiana: Indiana University Press.

Heidegger, Martin. 2003 [1989]. Beiträge zur Philosophie (Vom Ereignis). Frankfurt am Main: Vittorio Klostermann.

Janicaud, Dominique. 1985. La puissance du rationel. Paris: Gallimard.

Jünger, Friedrich Georg. 1946. Perfektion der Technik. Frankfurt am Main: Vittorio Klostermann.

Kiesel, Theodore. 2012 [1962]. A supratheoretical prescientific hermenutics of scientific discovery. In Heidegger on science, ed. Trish Glazebrook, 239-260. Albany: State University of New York Press.

Kleinberg, Ethan. 2005. Generation existential: Heidegger's philosophy in France, 1927-1961. Ithaca: Cornell University Press.

Kockelmans, Joseph J. 1985a. Heidegger and science. Washington, DC: Center for Advanced Research in Phenomenology and the University Press of America.

Kockelmans, Joseph J. 1985b. Heidegger on art and art works. Dordrecht: Martinus Nijhoff.

Kockelmans, Joseph J., and Theodor Kisiel (eds.). 1970. Phenomenology and the natural sciences. Evanston: Northwestern University Press.

Lacoue-Labarthe, Philippe. 2004. Prélude. In: Heidegger, la pauvréte (die Armut), 7-65. Strasbourg: Presses Universitaires de Strasbourg.

Levin, Thomas Y., and Michael von der Linn. 1994. Elements of a radio theory: Adorno and the Princeton radio research project. The Musical Quarterly 78(2): 316-324.

Lyon, James K. 2006. Paul Celan and Martin Heidegger: An unresolved conversation, 1951-1970. Baltimore: Johns Hopkins University Press.

Martin, Bernd (ed.). 1989. Martin Heideggerund das "Dritte Reich": ein Kompendium. Darmstadt: Wissenschaftlich Buchgesellschaft. 
Mitchell, Andrew. 2012. Translator's Foreword. In Heidegger, Bremen and Freiburg Lectures, Vii-xvi. Bloomington: Indiana University Press.

Mitchell, Andrew. English German glossary. In Heidegger, Bremen and Freiburg Lectures. 173-198. Indiana: Indiana University Press.

Nicholson, Graeme. 1987. The politics of Heidegger's rectoral address. Man and World 20: 171-187.

Nietzsche, Friedrich. 1980. Kritische Studienausgabe. ed. Giorgio Colli and Mazzino Montinari. Berlin. de Gruyter.

Packard, Vance. 1957. The hidden persuaders. New York: David McKay Co.

Polt, Richard. 2006. The emergency of being: On Heidegger's contributions to philosophy. Ithaca: Cornell University Press.

Rapaport, Herman. 1997. Forces of gravity. In Rapaport, Is there truth in art? 110-143. Ithaca: Cornell University Press.

Richardson, William J. 1993. [1963]. Heidegger: Through phenomenology to thought. 4th edition. New York: Fordham University Press.

Richter, Ewald. 1992. Heideggers Frage nach dem Gewährenden und die exakten Wissenschaften. Berlin: Duncker \& Humblot.

Richter, Ewald. 2012. Heidegger's theses concerning the question of the foundations of the sciences. In Heidegger on science, ed. Trish Glazebrook, 67-90. Albany: State University of New York Press.

Safranski, Rüdiger. 1999. Martin Heidegger: Between Good and Evil. Trans. Ewald Osers. Cambridge: Harvard University Press.

Sartre, Jean-Paul. 1946. L'existentialisme est un Humanisme. Paris: Les Éditions Nagel.

Sartre, Jean-Paul. 2007. Existentialism is a Humanism. Trans. Carol Macomber. New Haven: Yale University Press.

Seigfried, Hans. 1991. Heideggers Technikkritik. In Lebenswelt und Wissenschaft: Studien zum Verhältnis von Phänomenologie und Wissenschaftstheorie, ed. Carl Friedrich Gethman, 209-244. Bonn: Bouvier.

Sloane, Eric. 2004. [1965]. A reverence for wood. New York: Dover Publications.

Smythe, Dallas Walker. 1954. Reality as presented by television. The Public Opinion Quarterly 18(2): 143-156.

Winner, Langdon. 1986. The whale and the reactor. A search for limits in an age of high technology. Chicago: Chicago University Press. 